$\begin{array}{ll}\text { Research Square } & \begin{array}{l}\text { Preprints are preliminary reports that have not undergone peer review. } \\ \text { They should not be considered conclusive, used to inform clinical practice, } \\ \text { or referenced by the media as validated information. }\end{array}\end{array}$

\title{
Evolutionary Relationships, Phylogeographic Patterns, and a Hypothesis for Air- and Sea-driven Global Spread of Chromoblastomycosis by Etiological Fonsecaea Agents
}

huiWei Wang ( $\nabla$ wanghuiwei@smmu.edu.cn)

Shanghai Changzheng Hospital https://orcid.org/0000-0002-8055-4104

Juan Hao

Shanghai 9th Peoples Hospital Department of Ophthalmology

Liang-Qi Cai

The First Affiliated Hospital of Xiamen University

Min Chen

Shanghai Changzheng Hospital

Wen-Jie Fang

Shanghai Changzheng Hospital

Bo Pan

Shanghai Changzheng Hospital

Chao Zhang

Shanghai Changzheng Hospital

Xiao-Gang Liu

Shanghai Changzheng Hospital

Wen-Zhi Lei

Shanghai Changzheng Hospital

Lin Du

Shanghai Changzheng Hospital

Lei Zhang

Shaanxi Provincial People's Hospital

Cun-Wei Cao

The First Affiliated Hospital of Guangxi Medical University

Xiao-Chun Xue

905th Hospital of PLA Navy

Ya-li Yang

Shanghai Jiao Tong University School of Medicine Affiliated Ninth People's Hospital

Xiang-Fang Chen

Shanghai Changzheng Hospital

Ying Zhao

Shanghai Changzheng Hospital

Xiao-Jing Li

Affiliated Hospital of Hebei University

Ying Yang

Beijing Institute of Radiation Medicine

Li-Yan Ling

Pinghu Second People's Hospital,jiaxing

Wei-Wei Jiang

Shanghai Changzheng Hospital

Weihua Pan

Shanghai Changzheng Hospital https://orcid.org/0000-0001-7381-5188

Liu-qing Chen

Tongji Hospital of Tongji Medical College of Huazhong University of Science and Technology

Wan-Qing Liao

Shanghai Changzheng Hospital 
Keywords: Fonsecaea spp., diversity, gene flow, haplotypes, evolutionary outcomes, air-sea interaction

Posted Date: March 1st, 2022

DOI: https://doi.org/10.21203/rs.3.rs-1352980/v1

License: (c) (i) This work is licensed under a Creative Commons Attribution 4.0 International License. Read Full License 


\section{Abstract}

Fonsecaea spp. is the most common pathogen underlying chromoblastomycosis. However, many aspects of its evolutionary history are not fully understood, and a timescale for its diversification is lacking. Here, we propose, explain, and validate the evolutionary relationships, transmission routes, and modes of transmission among pathogenic species of the genus Fonsecaea . we investigated the sequences of a total of 510 intra-ribosomal transcribed regions and 485 reported cases of eight strains of the genus Fonsecaea, that have spread epidemically worldwide, persisted, and diversified over 38.27 million years. This period coincides with the diversification of many filamentous fungi, and this evolution explains the diversity and origin of pathogenic species of Fonsecaea spp . , as well as the possible transmission routes. Fonsecaea pedrosoi originated in the Atlantic Ocean near Brazil, F. monophora originated in the Pacific Ocean near southern China, and F. nubica originated in the Indian Ocean near Madagascar. F. pugnacius originated and is endemic in the Atlantic Ocean near Brazil. We proposed the hypothesis that non-pathogenic environmental strains in the environment ( Fonsecaea brasiliensis , F. multimorphosa , F. minima , and F. erecta ) evolved into pathogenic strains ( F. pedrosoi , F. pugnacius, F. nubica, and F. monophora) and spread globally with global tropical cyclone and ocean currents pathways. F. multimorphosa is potentially infectious to humans. The present study's results will greatly facilitate the prevention, treatment, and cure of Fonsecaea infections and give insight and reference to researchers in the field of fungal research, especially other pathogenic fungi and environmental fungi.

\section{Introduction}

Chromoblastomycosis (CBM) is a neglected, hard-curable, disabling, teratogenic, carcinogenic and progressive subcutaneous or cutaneous mycosis caused by traumatic inoculation with contaminated materials carrying inocula of the Herpotrichiellaceae family (Fungi; Dikarya, Ascomycota; saccharomyceta; Pezizomycotina; leotiomyceta; Eurotiomycetes; Chaetothyriomycetidae; Chaetothyriales (order)) (Breda et al., 2020). Fonsecaea spp. is the most common pathogen underlying CBM (Queiroz-Telles et al., 2017; Santos et al., 2021). At present, the Fonsecaea clade contains the clinically relevant species $F$. pedrosoi (Belda et al., 2020; de Andrade et al., 2020; Santos et al., 2007; Singh et al., 2006; Vicente et al., 2008), F. monophora (Campos-Macias et al., 2021), F. nubica (You et al., 2019) and F. pugnacius (Bombassaro et al., 2020). Infection by Fonsecaea spp. was first reported in 1911 in Brazil by Pedroso. Chromoblastomycosis caused by Fonsecaea spp. has been reported in countries including Argentina (Label et al., 2018), Venezuela (Paniz-mondolfi et al., 2008), Peru (Schwalb \& Seas, 2020), China (Bao et al., 2018; You et al., 2019; Zhang et al., 2019; Shen et al., 2020; Chen et al., 2021), India (Varghese et al., 2016), the United States (Takei et al., 2007), Mexico (Carolina et al., 2015), Canada (Mourad \& Haber, 2020), and Cuba (Badali et al., 2013). Molecular phylogenetic analyses have shown that several sibling species are involved. Fonsecaea erecta (Vicente et al., 2008; Vicente et al., 2017) and F. minima (Vicente et al., 2008) are commonly found in plant debris, while F. brasiliensis (Vicente \& Orelis-Ribeiro et al., 2012) is involved in infection of both animals (e.g., strain CBS 119710 in mangrove crab) and plants. F. multimorphosa (Najafzadeh et al., 2011; Leao et al., 2017) can also infect both animals (e.g., strain CBS 980.96 in cat brain abscess) and plants.

Because of the inclination to research human infections and environmental organisms separately, our recognition of the evolutionary relationships and phylogenetic connections among Fonsecaea spp. is fragmentary. Few studies have combined strains from different sources and geographic origins; furthermore, sampling procedures are generally limited to short periods of time or small samples. Despite this information barrier, localized incidences of infection by Fonsecaea spp. are strongly associated with an environmental source, typically involving traumatic injection of plant material into patients' cutaneous or subcutaneous tissues. Moreover, traditionally, assumptions about distribution, abundance, and ecological niches were defined by the study of morphological features and infection case reports. However, characteristics used to distinguish between clinical and environmental Fonsecaea species are reported to overlap. Consequently, cryptic entities have been underappreciated during the taxonomic development of this genus. At present, molecular biological methods are important for diagnosing CBM. Multilocus sequencing enhances the reliable categorization and in-depth investigations of distribution and biodiversity.

An increasing number of endemic tropical diseases caused by prevalent fungi(Boekhout et al., 2021), bacteria, viruses, and parasites are expanding their geographical distribution(Tedersoo et al., 2021), while a large number of natural products of tropical biomes have excellent therapeutic efficacy and show promise for treating these diseases (Adegboye et al., 2021). This provides new possible treatment options for the large number of patients with severe illnesses (Khan et al., 2019) or very poor treatment results (Schwalb \& Seas, 2020) who are currently widespread, because the complete cure of severe cases of Fonsecaea spp.-caused infections is a great challenge for clinicians and researchers (Santos et al., 2021). At present, the exact cost of CBM driven by etiological Fonsecaea agents is unknown, as there is no national surveillance mechanism in China to examine CBM in sentinel centers. Over the past century, large volumes of data have been gathered on a global basis, with hundreds of examples published in the past two decades alone. For example, the present study examined 238 articles containing case reports, case series, and outbreaks involving more than 485 cases. However, many aspects of the evolutionary history of Fonsecaea spp. are not fully understood, and a timescale for diversification is lacking. To understand the mechanisms for outbreak emergence, it is necessary to compare outbreak data with historical data on Fonsecaea spp. infections. Reinterpretation of historic data considering contemporary molecular phylogeny is thus necessary. In this study, we gathered pre-molecular literature that included interpretable case reports and geographic data. Strains from each of these locations were sequenced and identified, and the results compared with available published literature. Each of the detected species' frequencies was compared with the premise that their ranges in each region had remained mostly unchanged. Furthermore, molecular approaches were used to distinguish environmental and clinical isolates banked in the CBS culture collection (CBS-KNAW Fungal Biodiversity Centre, Utrecht, The Netherlands) over the last century, permitting phylogenetic analysis of human-pathogenic Fonsecaea spp. in relation to environmental- or animal-pathogenic species as well as to other species in Herpotrichiellaceae. This study provides a systematic and complete assessment of the molecular sequences of Fonsecaea spp. cases reported from 2000 to 2021 and published strains, describing phylogeographic patterns and evolutionary hypotheses in global transmission.

\section{Materials And Methods}

Research registration and ethics 
The design of this study was composed of three parts: 1) collection of cases and strain genes of Fonsecaea spp. in China and abroad; 2) an exploration of the origin and transmission pathways of pathogenic Fonsecaea spp. strains collected in the laboratory; and 3) the temporal phylogenetic tree and haplotype network validation. The systematic review part strictly followed the Preferred Reporting Items for Systematic Reviews and Meta-Analyses (PRISMA) statement. The research plan was reviewed and approved by the National Health Service (NHS), and assigned the PROSPERO registration number: CRD42021275308.

\section{Search strategy and inclusion criteria}

Literature reviews included the selection of all articles addressing worldwide epidemiology of chromoblastomycosis that were published in different languages (including Chinese, English, French, Japanese, and Spanish) between 2000 and 2021. Searching work done from PubMed and the Chineselanguage CNKI, SinoMed, and Wanfang databases. The search terms were (fungi[MeSH Terms]) AND (("Fonsecaea") OR ("monophora") OR ("pedrosol") OR ("multimorphosa") OR ("nubica") OR ("erecta") OR ("brasiliensis") OR ("minima") OR ("compacta") OR ("pugnacius") OR ("Trichosporum pedrosianum") OR ("Trichosporum pedrosol") OR ("Hormodendrum pedrosoi") OR ("Hormodendroides pedrosol") OR ("Rhinocladiella pedrosol") OR ("Phialophora pedrosoi") OR ("Gomphinaria pedrosoi") OR ("Carrionia pedrosol") OR ("Acrotheca pedrosoi")) OR (("Medlar body") OR ("Medlar bodies") OR ("sclerotic bodies")) AND ((Chromoblastomycoses) or (Chromomycos*s) or ("Dermatitis Verrucosa")). All studies in this thorough evaluation met the major CBM diagnostic criteria: 1$)$ A direct observation with $10 \%$ Potassium hydroxide revealed the presence of dark-colored, thick-walled muriform cells in a biological sample; and 2) fungal isolation was performed on Sabouraud dextrose agar, and Fonsecaea spp. was discovered using molecular analysis of strains taken from patients. Cultivation and DNA sequencing from culture verified the identity (Campos-Macias et al., 2021).

\section{Fungal strains}

All strains were kept in the CBS culture collection (https://wi.knaw.nl/) and PubMed's (https://www.ncbi.nlm.nih.gov/) reference collection under the name 'Fonsecaea'. All type strains that were available were included. Data on Fonsecaea spp. used in this investigation were obtained from GenBank (https://www.ncbi.nlm.nih.gov/); the accession numbers of the sequences utilized are presented in Supplementary Table 1. Cultures originated from the Centraalbureau voor Schimmelcultures (CBS-KNAW Fungal Biodiversity Centre, Utrecht, The Netherlands, https://www.gbif.org/dataset/82dc5194-f762-11e1a439-00145eb45e9a). Stock cultures were maintained on slants of Sabouraud's dextrose agar and Potato dextrose agar at $35^{\circ} \mathrm{C}$. Strains are listed in Supplementary Table 1.

\section{Genetic data analysis, dated phylogeny, and statistical analysis of collected strains}

Genetic data analysis, dated phylogeny, and statistical analysis of the collected strains ribosomal internal transcribed spacer (ITS) sequences were collected using MEGA v. 11 ((Kumar et al., 2018)), Sequence were aligned using the ClustalW option and a neighbor-joining tree was estimated using the Kimura 2parameter model plus gamma correction (K2 + G: 0.96), with 500 bootstrap replications. All temporal phylogenetic trees were built using the RelTime-ML method in MEGA v. 11 (Mello, 2018). Divergence times for Cryptococcus gattii, Candida albicans, Aspergillus fumigatus, and Pyrenula anomala are referenced on the website (http://www.timetree.org /search/goto_pairwise), and the searched divergence times were used as calibration time points for the molecular clock to infer evolutionary times. DnaSP v.6 (Rozas et al., 2017) on the Universitat de Barcelona server (http://www.ub.edu/dnasp/) was used to determine the extent of DNA polymorphism. All haplotype network models were constructed using PopART 1.7 (http://popart.otago.ac.nz/index.shtml; Clement et al., 2000). Categorical variables were compared with chi-square tests. Differences between groups were considered statistically significant if P-values were $\leq 0.05$. Divergence times are reported in millions of years ago (Ma).

\section{Results}

\section{Information on the characteristics of the collected global cases and strains}

The study included a total of 498 CBM cases that were published. The worldwide distribution and prevalence of CBM cases are shown respectively in Fig. 1 , while the main characteristics of CBM are illustrated by countries and continents as summarized in Supplementary Table 1. A total of 510 Fonsecaea spp. were evaluated, of which 44 were environmental plant, and four were animal. Data obtained on geographic origins and sources of isolation are listed in Supplementary Table 2. Regions with a high incidence of cases include Brazil, Venezuela, and Colombia (South America); Mexico, Cuba, and the United States (North America); China, India, Vietnam, and Japan (Asia); Madagascar (Africa); and France and the Netherlands (Europe). We compared the number of isolated Fonsecaea spp. strains with the number of reported cases of

chromoblastomycosis caused by this fungus in the same time period, showing the same trend. From 2000 to the first half of 2021 , the number of reported cases and strains of Fonsecaea spp. infections were increased progressively, and both showed a consistent trend.

In each 4-year period, we found that the number of cases of the four pathogenic species increased over time, with the most pronounced increases in $F$. pedrosoi and F. monophora. Fonsecaea pedrosoi and F. monophora had the highest number of cases and isolated strains among patients. 
Table 1

Estimated distributions of molecular species on the basis of percentages of sequenced strains compared to the total number of published cases in the respec

\begin{tabular}{|c|c|c|c|c|c|c|c|c|c|c|}
\hline $\begin{array}{l}\text { Continent } \\
\text { / region }\end{array}$ & Country & $\begin{array}{l}\text { Sequenced } \\
\text { isolates }\end{array}$ & F.pedrosoi & F.monophora & F.nubica & F.pugnacius & $\begin{array}{l}F \\
\text { brasiliensis }\end{array}$ & $\begin{array}{l}\text { F. } \\
\text { erecta }\end{array}$ & $\begin{array}{l}\text { F. } \\
\text { minima }\end{array}$ & F.multimorph \\
\hline \multirow{6}{*}{$\begin{array}{l}\text { South } \\
\text { America } \\
(316)\end{array}$} & Argentina & 3 & $3(100 \%)$ & & & & & & & \\
\hline & Brazil & 268 & 193(70\%) & $23(8 \%)$ & $9(3 \%)$ & $4(1 \%)$ & $16(6 \%)$ & $6(2 \%)$ & $10(4 \%)$ & $7(3 \%)$ \\
\hline & Colombia & 3 & $3(100 \%)$ & & & & & & & \\
\hline & Costa Rica & 12 & 10(83.3\%) & $2(17 \%)$ & & & & & & \\
\hline & Uruguay & 4 & $1(25 \%)$ & & & & $2(50 \%)$ & $1(25 \%)$ & & \\
\hline & Venezuela & 14 & $14(100 \%)$ & & & & & & & \\
\hline \multirow{7}{*}{$\begin{array}{l}\text { Asia } \\
(105)\end{array}$} & China & 82 & $3(4 \%)$ & $59(72 \%)$ & $19(23 \%)$ & & & $1(1 \%)$ & & \\
\hline & India & 6 & & $6(100 \%)$ & & & & & & \\
\hline & Japan & 10 & $10(100 \%)$ & & & & & & & \\
\hline & Malaysia & 2 & & $2(100 \%)$ & & & & & & \\
\hline & Korea & 1 & & $1(100 \%)$ & & & & & & \\
\hline & Surinam & 2 & $1(50 \%)$ & & $1(50 \%)$ & & & & & \\
\hline & Thailand & 2 & $1(50 \%)$ & $1(50 \%)$ & & & & & & \\
\hline \multirow{2}{*}{$\begin{array}{l}\text { Oceania } \\
\text { (4) }\end{array}$} & Australia & 3 & 1(33\%) & $1(33 \%)$ & & & & & & $1(33 \%)$ \\
\hline & Queensland & 1 & & & & & & & & $1(100 \%)$ \\
\hline \multirow{6}{*}{$\begin{array}{l}\text { Africa } \\
(54)\end{array}$} & Cameroon & 1 & & & $1(100 \%)$ & & & & & \\
\hline & Congo & 2 & $1(50 \%)$ & $1(50 \%)$ & & & & & & \\
\hline & Guinea & 1 & & $1(100 \%)$ & & & & & & \\
\hline & Libya & 1 & $1(100 \%)$ & & & & & & & \\
\hline & Madagascar & 47 & $2(4.3 \%)$ & $23(48.9 \%)$ & $22(46.8 \%)$ & & & & & \\
\hline & Mozambique & 1 & $1(100 \%)$ & & & & & & & \\
\hline \multirow[t]{5}{*}{$\begin{array}{l}\text { Europe } \\
(9)\end{array}$} & $\begin{array}{l}\text { Czech } \\
\text { Republic }\end{array}$ & 2 & $1(50 \%)$ & $1(50 \%)$ & & & & & & \\
\hline & England & 1 & & $1(100 \%)$ & & & & & & \\
\hline & France & 2 & & $1(50 \%)$ & $1(50 \%)$ & & & & & \\
\hline & Netherlands & 3 & $1(33 \%)$ & $1(33 \%)$ & $1(33 \%)$ & & & & & \\
\hline & Poland & 1 & $1(100 \%)$ & & & & & & & \\
\hline \multirow{4}{*}{$\begin{array}{l}\text { North } \\
\text { America } \\
\text { (35) }\end{array}$} & Cuba & 9 & $5(56 \%)$ & $4(44 \%)$ & & & & & & \\
\hline & Mexico & 16 & $4(25 \%)$ & $12(75 \%)$ & & & & & & \\
\hline & Puerto Rico & 2 & $2(100 \%)$ & & & & & & & \\
\hline & USA & 8 & $2(25 \%)$ & $6(75 \%)$ & & & & & & \\
\hline Total & 32 & 510 & $268(51.7 \%)$ & $147(28.6 \%)$ & $54(10.6 \%)$ & $4(0.8 \%)$ & $18(3.5 \%)$ & $8(1.6 \%)$ & $10(2.0 \%)$ & $9(1.8 \%)$ \\
\hline
\end{tabular}

Phylogenetic analysis revealed that the eight species of Fonsecaea spp. (F. brasiliensis, F. multimorphosa, F. minima, F. erecta, F. pedrosoi, F. nubica, F. pugnacius, and F. monophora) were clearly divided into eight major groups (Fig. 2). Most strains belonged to F. pedrosoi, F. nubica, and F. monophora. It is worth noting that among the F. pedrosoi strains, the Costa Rican and Brazilian strains have similar homology to those from Argentina, Brazil, Uruguay, Mexico, Venezuela, the United States, Puerto Rico, and China. Among F. monophora strains, the pathogenic strain from Guangdong, China has similar homology to both environmental and pathogenic strains from Guangdong, Nanjing, Shanghai, Shandong, and Taiwan (all from China), Japan, Korea, Malaysia, Vietnam, India, Costa Rica, Cuba, France, UK, Netherlands, Czech Republic, Kuwait, the United States, Africa, Guinea, and Brazil. Among the strains of $F$. nubica, those of 
Madagascar are most similar to those of Mozambique, Cameroon, Congo, China, and Japan. F. erecta and F. monophora strains were isolated only from the environments of Australia, China, and Uruguay, while the other strains were mostly found in Brazil.

\section{Divergence times of Fonsecaea spp. revealed by temporal phylogenetic tree}

Using Cryptococcus gattii (divergence time: $723 \mathrm{Ma}$ [626-806 Ma]), Candida albicans (divergence time: 590 Ma [480-713 Ma]), Aspergillus fumigatus (divergence time: $307 \mathrm{Ma}$ [275-403 Ma]) and Pyrenula anomala (divergence time: 304.46 Ma [217-402 Ma]) as temporal reference standards, the divergence between the genera Cladophialophora and Fonsecaea was estimated at $94.15 \mathrm{Ma}$ (the timetree figure is included in supplementary information). After 51.63 million years (around $38.27 \mathrm{Ma}$ ), Fonsecaea spp. began diversifying to survive in decaying organic matter, living plants, and animals (e.g., mangrove crab), with F. brasiliensis diverging first, followed by F. multimorphosa (around $21.30 \mathrm{Ma}$ ), F. minima (around $20.01 \mathrm{Ma}$ ), and F. erecta (around $19.11 \mathrm{Ma}$ ). A rough estimate of the divergence time of the globally epidemic F. pedrosoi. is around $17.41 \mathrm{Ma}$. The other main pathogenic species $F$. pugnacius, $F$. nubica, and $F$. monophora all diverged subsequently at $\sim 8.23 \mathrm{Ma}, \sim 1.64 \mathrm{Ma}$, and $\sim 0.08 \mathrm{Ma}$, respectively (The timetree was included in supplementary information).

In the haplotype network model, the selected Fonsecaea sequences are all identified human-pathogenic and non-pathogenic species from Brazil (Fig. 3). Among the identified human-pathogenic species: F. pedrosoi has the greatest haplotype diversity (hap9, 12, 14, 15, 16, 17, 18, 19, 20, and 21). Fonsecaea monophora, F. nibica, and F. pugnacius are all closely related to F. pedrosoi. Fonsecaea multimorphosa has six haplotypes (hap5, 6, 7, 8, 9, and10), one of which (hap9) has the same sequence as that of $F$. pedrosoi. It is worth noting that $F$. multimorphosa also has a close evolutionary relationship to $F$. pedrosoi, although no human infection has been reported, infections of mammalian (e.g., cat) brains by F. multimorphosa have been reported (Leao et al., 2017).

\section{Hypothesis on the origin and mode of dispersal of Fonsecaea spp.}

Based on the dated phylogenetic tree and haplotype network model of the collected global Fonsecaea spp. gene sequences, we inferred the origin of the now globally prevalent pathogenic species of Fonsecaea. Fonsecaeapedrosoi may be from the marine area near Costa Rica, Colombia, or Brazil (including the eastern and northern waters of the Pacific Ocean and the northern waters of the Atlantic Ocean) (Fig. 4), as this region has the highest haplotype diversity of the F. pedrosoi gene and the highest number of haplotype genes. The haploid genotypes of Venezuela, Colombia, Uruguay, Argentina, Costa Rica, Mexico, the United States, Cuba, France, Netherlands, Congo, Libya, Madagascar, Australia, Thailand, Vietnam, China, and Japan can all be found in Brazil (Fig. 4). The origin of the pathogenic strain F. nubica appears to be in the ocean near Madagascar, and the strain has likely been spread by frequent Indian Ocean tropical cyclones or super typhoons (Fig. 5) to countries including China, Vietnam, France, Italy, Cameroon, and Brazil. Fonsecaea monophora strain likely originated in the maritime region near China (Fig. 6) and is now endemic to regions including southeastern China, India, Thailand, the Philippines, Madagascar, Australia, the United Kingdom, the United States, Mexico, Cuba, Costa Rica, and Brazil. Fonsecaea pugnacius originated and remains prevalent in the Atlantic Ocean near Brazil. Our predicted regions of origin of these pathogenic strains of Fonsecaea spp. are very similar to the global regions of origin of many tropical cyclones (Fig. 7). The transmission chain of this fungus is also very similar to the movement path of global tropical cyclones, so we hypothesize that the transfer path of tropical cyclones facilitates the global spread of the pathogen (Fig. 8).

In the absence of strain mutations, mycelia, spores, dormant bodies of Fonsecaea spp., or carriers containing the fungus are carried into the air with the onset of tropical cyclones in the northern hemisphere from June to October. The airborne fungus spreads randomly along the path of a tropical hurricane as the storm's path shifts. This fungus grows slowly and has a suitable temperature of $23-40^{\circ} \mathrm{C}$ (de Azevedo et al., 2015).

\section{Discussion}

Chromoblastomycosis (CBM) is a globally occurring mycosis caused principally by infectious strains of Fonsecaea spp. Despite their global distribution and increasing disease prevalence, the relationships to environmentally occurring strains and modes of global spread remain poorly understood. In this study, we combined data from a variety of sources (case reports, molecular data, and meteorological data) to provide a comprehensive assessment of and to derive a hypothesis for the evolution and transmission of infectious strains of Fonsecaea spp., the main causative agent of chromoblastomycosis.

\section{Evolutionary relationships and divergences of infectious Fonsecaea spp. strains}

Divergence time estimates indicated surprising antiquity of the major clades within Fonsecaea. Around 38.27 Ma, Fonsecaea spp. began diversifying to survive in decaying matter, living plants, and animals (e.g., mangrove crab), with $F$. brasiliensis diverging first. This was followed by divergences of $F$. multimorphosa ( 21.30 Ma), F. minima ( 20.01 Ma), and F. erecta ( 19.11 Ma), but no human infection by these species has yet been reported. About 17.41 million years ago, a strain of F. pedrosoi, the main causative species of CBM, reported today in the vicinity of Costa Rica and Brazil, emerged and subsequently spread throughout the world. Fonsecaea pugnacius, F. nubica, and F. monophora, which are all in the clade subtended by the aforementioned F. pedrosoi strain, have all gradually diverged and been reported as infectious. These estimated divergence times are considerably earlier than previously recognized and coincide with the divergences of many other filamentous fungi (Beimforde et al., 2014; Kumar et al., 2017; Lücking et al., 2009; Riess et al., 2016; Steenwyk et al., 2019; Taylor \& Berbee, 2006). This suggests that these pathogenic strains of Fonsecaea spp. should be more broadly infectious toward mammals in general, as they also coincide with the earliest known divergences within the hominin clade (Bramble \& Lieberman, 2004; Wallis et al., 2008). The evolutionary relationships are supported by the haplotype network, where the three other identified human-pathogenic species (F. monophora, F. nubica, and F. pugnacius) are all most closely related to $F$. pedrosoi, the principal causative agent of CBM. It is worth noting that $F$. multimorphosa also has a very close evolutionary relationship to F. pedrosoi (Fig. 3); although no human infection has been reported, F. multimorphosa infection has been reported in cat brains, so it should be considered potentially infectious to humans as well.

Geographic origin and air/sea-driven dispersal of infectious Fonsecaea spp. strains 
Combined analyses indicate that pathogenic Fonsecaea pedrosoi originated in the Atlantic Ocean near Costa Rica or Brazil and is now endemic worldwide (Fig. 4), F. monophora originated in the Pacific Ocean near southern China (Fig. 5), F. nubica originated in the Indian Ocean near Madagascar (Fig. 6), and F. pugnacius originated and is endemic in the Atlantic Ocean near Brazil. These predicted areas of origin of Fonsecaea variants are very similar to those of tropical cyclones (Fig. 7). The tropical oceans produce about 80 tropical storms per year, of which about two-thirds are severe (classified on a Saffir-Simpson intensity scale of 1 or higher). Almost $90 \%$ of storms form within $20^{\circ}$ north or south of the equator (Britannica, 2022; National Hurricane Center and Central Pacific Hurricane Center National Oceanic and Atmospheric Administration, 2022), and CBM is also endemic in this region (Queiroz-Telles et al., 2017; Santos et al., 2021). Notably, the findings of DeLeon-Rodriguez et al., (2013) (DeLeon-Rodriguez et al., 2013) suggested that fogging of large fungal spore communities occurs during tropical hurricanes, and airborne fungi may remain viable after being carried aloft (Alsante et al., 2021; Mayer et al., 2020), where long-distance, transcontinental and even oceanic transport occurs. The fungal microbiota is a dynamic and underappreciated aspect of the lower oceanic layer, and the extensive flooding after mega-hurricanes can create ideal conditions (Barbeau et al., 2010) for the growth of molds such as Fonsecaea spp. (Bloom et al., 2009). Additionally, talaromycosis (penicilliosis) caused by invasive mycotic infection has been found to be highly associated with cyclones and floods during the tropical monsoon season (Narayanasamy et al., 2021).

Filamentous fungi and ascomycetes can grow in both natural and artificial seawater media. Salinity, water temperature, dissolved oxygen, and pH in seawater do not strongly affect growth of fungal communities, even of mycelia resting over long periods (Mouton et al., 2012; Manohar \& Raghukumar, 2013; Rédou et al., 2015; Wijesekera et al., 2017; Grossart et al., 2019; Rojas-Jimenez et al., 2020). Fungi have been discovered in practically every marine ecosystem studied (Gladfelter et al., 2019; Grossart et al., 2019), including deep subsurface sediments (Rédou et al., 2014; Gladfelter et al., 2019; Vargas-Gastélum \& Riquelme, 2020), coastal plankton (Taylor \& Cunliffe, 2016), wood (Rämä et al., 2016; Lee et al., 2019; Rahaman et al., 2020), and marine animals (Wainwright et al., 2017; Amend et al., 2019) at depths ranging from the deep sea to surface waters (Amend et al., 2019). In addition, ascomycetes species are generally considered to be more tolerant of extreme environments (Rämä et al., 2016; Vargas-Gastélum \& Riquelme, 2020). Fonsecaea erecta (strain 14A-2) was found in marine sponges in the South China Sea area (Qin et al., 2015). Fonsecaea pedrosoi has been found in very diverse environments including a babassu coconut shell (Marques et al., 2006), mouse passage soil (Najafzadeh et al., 2009), plant debris (Irinyi et al., 2015), and termite nests (Lima et al., 2020). Fonsecaea monophora has been found on fur seals (De Hoog et al., 2004), and a decaying babassu coconut shell (Vicente et al., 2014), while F. brasiliensis was found on mangrove crabs (Vicente \& Orélis-Ribeiro et al., 2012).

As there seems to be a very strong correlation between tropical cyclones (hurricanes and typhoons) and the prevalence of the pathogenic fungus Fonsecaea spp., we conjecture that the widespread presence of this fungus in the ocean (from deep-sea sediments, decaying and living marine plants, and dead and living animals to microorganisms or floating material on the ocean surface), or zones close to the ocean, provides a source for the transmission of fungal pathogens including Fonsecaea spp. (both environmental and pathogenic strains). Frequent tropical cyclones provide a source of power and means of dispersing fungal pathogens. Small items such as fungal mycelia, spores, and dormant bodies can be transported by the tens of thousands in the air or on a carrier or container. Strong carrying capacity and lethality of tropical cyclones carrying Fonsecaea-containing materials, mixed with seawater and rainwater, can enable rapid long-distance transfer and wide seeding of highly durable pathogenic fungi across continents and even large oceans. Flooded target areas containing many injured and dead plants and animals provide good breeding environments for storm-dispersed fungi. In addition, the direction of ocean currents may further promote fungal dispersal by transporting floating rotting wood, marine microorganisms, and other propagation media carrying environmentally resistant fungal particles to new regions with suitable climatic conditions. The formation of the fungus like seeds in the global rapid spread and slow long-term spread of the mixed way. The mixture of faster and slower means of dispersal contributes to rapid global expansion of fungal communities. The combination of these factors has resulted in worldwide reports of infections and the isolation of globally occurring pathogenic Fonsecaea spp. and variants collected to date. In terms of genetic evolution of the strains, there is a mixture of primary and secondary strains, indigenous mutants, and exotic variants (across continents and oceans). Our findings indicate that F. pedrosoi has the most reported regional cases with strains in Brazil, F. monophora has the most reported cases near China, and F. nubica has the most reported cases in Madagascar, with haplotype networks of these three pathogenic species showing the greatest genotypic diversity. Our findings and proposed hypothesis for transmission have potentially important implications for better understanding not only the spread of invasive pathogenic fungi such as Fonsecaea spp., but hydrographic oceanic circulation, cloud dispersal, and fungal biogeographic dispersal science in general.

\section{Conclusion}

The data that could be collected so far may still be distant from the true picture of the genetic evolution and global modes and patterns of transmission of Fonsecaea spp., leading us to only roughly identify the regions of origin of the pathogenic fungi $F$. pedrosoi, F. monophora, F. nubica, and $F$. pugnacius. In this paper we propose, explain, and validate the evolutionary relationships, transmission routes, and modes of transmission among pathogenic species of the genus Fonsecaea. The results of the present study will give insight and reference to researchers in the field of fungal research, especially the global transmission mode and pattern of Fonsecaea spp.. This study represents a new breakthrough not only in relation to Fonsecaea spp., but also by providing a reference for examining the transmission mode, pathway and genetic evolution of other clinically relevant pathogenic fungi and environmental fungi, including the genera Candida (Boekhout et al., 2021), Aspergillus, Cryptococcus, and Zygomycetes (Mucor) and other environmental fungi (Devadatha et al., 2021).

\section{Declarations}

\section{Statements and declarations}

Supplementary Information The online version contains supplementary material available. 


\section{Funding:}

This work was supported by the National Natural Science Foundation of China (82072257, 81720108026, and 31770161), Shanghai Science and Technology Committee (21410750500, 20DZ2272900, and 19YF1448000), Guangxi Science and Technology Agency (2020GXNSFGA238001), Chinese Academy of Engineering (2020-XY-61-01), and National Natural Science Foundation of China Youth Program (82002124)

\section{Competing interests:}

The authors declare no conflicts of interests.

Ethical approval Not applicable.

Consent to participate Not applicable.

Consent for publication All authors give their consent to publish this study in Fungal Diversity

\section{Author contributions}

All authors contributed to the study conception and design. Material preparation, data collection and analysis were performed by HuiWei Wang and WeiHua Pan. The first draft of the manuscript was written by HuiWei Wang and WeiHua Pan. All authors participated in the data analysis, manuscript editing process and all authors commented on previous versions of the manuscript. All authors read and approved the final manuscript.

\section{Acknowledgments}

We thank Gabe Yedid, PhD, from Liwen Bianji (https://www.liwenbianji.cn/), for editing the English text of a draft of this manuscript.

\section{Availability of data and material}

Data are partly presented in Supplementary Table 1, and 2. Data on Fonsecaea spp. used in this investigation were obtained from GenBank (https://www.ncbi.nlm.nih.gov/); Cultures originated from the Centraalbureau voor Schimmelcultures (CBS-KNAW Fungal Biodiversity Centre, Utrecht, The Netherlands, https://www.gbif.org/dataset/82dc5194-f762-11e1-a439-00145eb45e9a).This and all other relevant datasets generated during and/or analysed during the current study are available from the corresponding author on reasonable request.

\section{References}

Alsante, A. N., Thornton, D. C. O., \& Brooks, S. D. (2021). Ocean Aerobiology. Frontiers in Microbiology, 12, 764178. https://doi.org/10.3389/fmicb.2021.764178

Amend, A., Burgaud, G., Cunliffe, M., Edgcomb, V. P., Ettinger, C. L., Gutiérrez, M. H., Heitman, J., Hom, E. F. Y., laniri, G., Jones, A. C., Kagami, M., Picard, K. T., Quandt, C. A., Raghukumar, S., Riquelme, M., Stajich, J., Vargas-Muñiz, J., Walker, A. K., Yarden, O., \& Gladfelter, A. S. (2019). Fungi in the Marine Environment: Open Questions and Unsolved Problems. mBio, 10(2) https://doi.org/10.1128/mBio.01189-18

Badali, H., Fernandez-Gonzalez, M., Mousavi, B., Illnait-Zaragozi, M. T., Gonzalez-Rodriguez, J. C., de Hoog, G. S., \& Meis, J. F. (2013). Chromoblastomycosis due to Fonsecaea pedrosoi and F. monophora in Cuba [Case Reports; Journal Article; Research Support, Non-U.S. Gov't]. Mycopathologia, 175(5-6), 439444. https://doi.org/10.1007/s11046-013-9634-3

Bao, F., Wang, Q., Yu, C., Shang, P., Sun, L., Zhou, G., Wu, M., \& Zhang, F. (2018). Case Report: Successful Treatment of Chromoblastomycosis Caused by Fonsecaea monophora in a Patient with Psoriasis Using Itraconazole and Acitretin. The American journal of tropical medicine and hygiene, 99(1), 124126. https://doi.org/10.4269/ajtmh.17-0579

Barbeau, D. N., Grimsley, L. F., White, L. E., El-Dahr, J. M., \& Lichtveld, M. (2010). Mold exposure and health effects following hurricanes Katrina and Rita. Annual Review of Public Health, 31, 165-178. https://doi.org/10.1146/annurev.publhealth.012809.103643

Beimforde, C., Feldberg, K., Nylinder, S., Rikkinen, J., Tuovila, H., Dörfelt, H., Gube, M., Jackson, D. J., Reitner, J., Seyfullah, L. J., \& Schmidt, A. R. (2014). Estimating the Phanerozoic history of the Ascomycota lineages: combining fossil and molecular data. Molecular phylogenetics and evolution, 78, 386398. https://doi.org/10.1016/j.ympev.2014.04.024

Belda, W. J., Criado, P. R., \& Passero, L. (2020). Successful treatment of chromoblastomycosis caused by Fonsecaea pedrosoi using imiquimod [Case Reports; Journal Article]. The Journal of dermatology, 47(4), 409-412. https://doi.org/10.1111/1346-8138.15225

Bloom, E., Grimsley, L. F., Pehrson, C., Lewis, J., \& Larsson, L. (2009). Molds and mycotoxins in dust from water-damaged homes in New Orleans after hurricane Katrina. Indoor air, 19(2), 153-158. https://doi.org/10.1111/j.1600-0668.2008.00574.x

Boekhout, T., Amend, A. S., El Baidouri, F., Gabaldón, T., Geml, J., Mittelbach, M., Robert, V., Tan, C. S., Turchetti, B., Vu, D., Wang, Q. M., \& Yurkov, A. (2021). Trends in yeast diversity discovery. Fungal Diversity(2021) https://doi.org/10.1007/s13225-021-00494-6 
Bombassaro, A., Schneider, G. X., Costa, F. F., Leao, A., Soley, B. S., Medeiros, F., Da, S. N., Lima, B., Castro, R., Bocca, A. L., Baura, V. A., Balsanelli, E., Pankievicz, V., Hrysay, N., Scola, R. H., Moreno, L. F., Azevedo, C., Souza, E. M., Gomes, R. R., de Hoog, S., \& Vicente, V. A. (2020). Genomics and Virulence of Fonsecaea pugnacius, Agent of Disseminated Chromoblastomycosis. Frontiers in Genetics, 11, 822. https://doi.org/10.3389/fgene.2020.00822

Bramble, D. M., \& Lieberman, D. E. (2004). Endurance running and the evolution of Homo. Nature, 432(7015), 345-352. https://doi.org/10.1038/nature03052

Breda, L. C. D., Menezes, I. G., Paulo, L. N. M., \& de Almeida, S. R. (2020). Immune Sensing and Potential Immunotherapeutic Approaches to Control Chromoblastomycosis. Journal of fungi (Basel, Switzerland), 7(1) https://doi.org/10.3390/jof7010003

Britannica. (2022). tropical cyclone - Location and patterns of tropical cyclones Retreved 2022-1-5 from https://www.britannica.com/science/tropical-cyclone

Campos-Macias, P., Arenas, R., Aquino, C. J., Romero-Navarrete, M., Martinez-Hernandez, F., Martinez-Chavarria, L. C., Xicohtencatl-Cortes, J., \& HernandezCastro, R. (2021). Chromoblastomycosis caused by Fonsecaea monophora in Mexico [Case Reports]. Journal de mycologie medicale, 31(2),

101114. https://doi.org/10.1016/j.mycmed.2021.101114

Carolina, R. O., Leon-Cachon, R. B., Perez-Maya, A. A., Aguirre-Garza, M., Moreno-Trevino, M. G., \& Gonzalez, G. M. (2015). Phenotypic and molecular identification of Fonsecaea pedrosoi strains isolated from chromoblastomycosis patients in Mexico and Venezuela. Mycoses, 58(5), 267-

272. https://doi.org/10.1111/myc. 12308

Chen, W., Lin, T., Chen, H., Zhao, Y., Wang, L., \& Yang H. (2021). Chromomycosis caused by Fonsecaea compacta (Fonsecaea Pedrosoi). Journal of Clinical Dermatology, 50(02), 93-96. https://doi.org/10.16761/j.cnki.1000-4963.2021.02.009

de Andrade, T. S., de Almeida, A. M. Z., Basano, S. D. A., Takagi, E. H., Szeszs, M. W., Melhem, M. S. C., Albuquerque, M., Camargo, J. D. S. A., Gambale, W., \& Camargo, L. M. A. (2020). Chromoblastomycosis in the Amazon region, Brazil, caused by Fonsecaea pedrosoi, Fonsecaea nubica, and Rhinocladiella similis: Clinicopathology, susceptibility, and molecular identification. Medical mycology, 58(2), 172-180. https://doi.org/10.1093/mmy/myz034

de Azevedo, C. M. P. S., Gomes, R. R., Vicente, V. A., Santos, D. W. C. L., Marques, S. G., do Nascimento, M. M. F., Andrade, C. E. W., Silva, R. R., Queiroz-Telles, F., \& de Hoog, G. S. (2015). Fonsecaea pugnacius, a Novel Agent of Disseminated Chromoblastomycosis. Journal of clinical microbiology, 53(8), 26742685. https://doi.org/10.1128/JCM.00637-15

De Hoog, G. S., Attili-Angelis, D., Vicente, V. A., Van Den Ende, A. H. G. G., \& Queiroz-Telles, F. (2004). Molecular ecology and pathogenic potential of Fonsecaea species. Medical mycology, 42(5), 405-416. https://doi.org/10.1080/13693780410001661464

DeLeon-Rodriguez, N., Lathem, T. L., Rodriguez-R, L. M., Barazesh, J. M., Anderson, B. E., Beyersdorf, A. J., Ziemba, L. D., Bergin, M., Nenes, A., \& Konstantinidis, K. T. (2013). Microbiome of the upper troposphere: species composition and prevalence, effects of tropical storms, and atmospheric implications. Proceedings of the National Academy of Sciences of the United States of America, 110(7), 2575-2580. https://doi.org/10.1073/pnas.1212089110

Devadatha, B., Jones, E. B. G., Pang, K. L., Abdel-Wahab, M. A., Hyde, K. D., Sakayaroj, J., Bahkali, A. H., Calabon, M. S., Sarma, V. V., Sutreong, S., \& Zhang, S. N. (2021). Occurrence and geographical distribution of mangrove fungi. Fungal Diversity, 106, 137-227. https://doi.org/10.1007/s13225-020-00468-0

Gladfelter, A. S., James, T. Y., \& Amend, A. S. (2019). Marine fungi. Current biology: CB, 29(6), 191-195. https://doi.org/10.1016/j.cub.2019.02.009

Grossart, H., Van den Wyngaert, S., Kagami, M., Wurzbacher, C., Cunliffe, M., \& Rojas-Jimenez, K. (2019). Fungi in aquatic ecosystems. Nature reviews. Microbiology, 17(6), 339-354. https://doi.org/10.1038/s41579-019-0175-8

Irinyi, L., Serena, C., Garcia-Hermoso, D., Arabatzis, M., Desnos-Ollivier, M., Vu, D., Cardinali, G., Arthur, I., Normand, A., Giraldo, A., da Cunha, K. C., SandovalDenis, M., Hendrickx, M., Nishikaku, A. S., de Azevedo Melo, A. S., Merseguel, K. B., Khan, A., Parente Rocha, J. A., Sampaio, P., da Silva Briones, M. R., e Ferreira, R. C., de Medeiros Muniz, M., Castañón-Olivares, L. R., Estrada-Barcenas, D., Cassagne, C., Mary, C., Duan, S. Y., Kong, F., Sun, A. Y., Zeng, X., Zhao, Z., Gantois, N., Botterel, F., Robbertse, B., Schoch, C., Gams, W., Ellis, D., Halliday, C., Chen, S., Sorrell, T. C., Piarroux, R., Colombo, A. L., Pais, C., de Hoog, S., Zancopé-Oliveira, R. M., Taylor, M. L., Toriello, C., de Almeida Soares, C. M., Delhaes, L., Stubbe, D., Dromer, F., Ranque, S., Guarro, J., Cano-Lira, J. F., Robert, V., Velegraki, A., \& Meyer, W. (2015). International Society of Human and Animal Mycology (ISHAM)-ITS reference DNA barcoding database-the quality controlled standard tool for routine identification of human and animal pathogenic fungi. Medical mycology, 53(4), 313-337. https://doi.org/10.1093/mmy/myv008

Kumar, S., Stecher, G., Li, M., Knyaz, C., \& Tamura, K. (2018). MEGA X: Molecular Evolutionary Genetics Analysis across Computing Platforms. Molecular biology and evolution, 35(6), 1547-1549. https://doi.org/10.1093/molbev/msy096

Kumar, S., Stecher, G., Suleski, M., \& Hedges, S. B. (2017). TimeTree: A Resource for Timelines, Timetrees, and Divergence Times. Molecular biology and evolution, 34(7), 1812-1819. https://doi.org/10.1093/molbev/msx116

Label, M., Karayan, L. C., De Hoog, S., Afeltra, J., Bustamante, T., \& Vitale, R. G. (2018). Differential distribution patterns of Fonsecaea agents of chromoblastomycosis, exemplified by the first case due to F. monophora from Argentina. Medical mycology case reports, 20, 35-

38. https://doi.org/10.1016/j.mmcr.2017.11.002 
Leao, A. C. R., Weiss, V. A., Vicente, V. A., Costa, F., Bombassaro, A., Raittz, R. T., Steffens, M. B. R., Pedrosa, F. O., Gomes, R. R., Baura, V., Faoro, H., Sfeir, M. Z. T., Balsanelli, E., Moreno, L. F., Najafzadeh, M. J., de Hoog, S., \& Souza, E. M. (2017). Genome Sequence of Type Strain Fonsecaea multimorphosa CBS 980.96(T), a Causal Agent of Feline Cerebral Phaeohyphomycosis. Genome announcements, 5(7) https://doi.org/10.1128/genomeA.01666-16

Lee, N. L. Y., Huang, D., Quek, Z. B. R., Lee, J. N., \& Wainwright, B. J. (2019). Mangrove-Associated Fungal Communities Are Differentiated by Geographic Location and Host Structure. Frontiers in Microbiology, 10, 2456. https://doi.org/10.3389/fmicb.2019.02456

Lima, B. J. F. D., Voidaleski, M. F., Gomes, R. R., Fornari, G., Soares, J. M. B., Bombassaro, A., Schneider, G. X., Soley, B. D. S., de Azevedo, C. D. M. P., Menezes, C., Moreno, L. F., Attili-Angelis, D., Klisiowicz, D. D. R., de Hoog, S., \& Vicente, V. A. (2020). Selective isolation of agents of chromoblastomycosis from insectassociated environmental sources. Fungal Biology, 124(3-4), 194-204. https://doi.org/10.1016/j.funbio.2020.02.002

Lücking, R., Huhndorf, S., Pfister, D. H., Plata, E. R., \& Lumbsch, H. T. (2009). Fungi evolved right on track. Mycologia, $101(6), 810-822$.

https://doi.org/10.3852/09-016

Manohar, C. S., \& Raghukumar, C. (2013). Fungal diversity from various marine habitats deduced through culture-independent studies. FEMS microbiology letters, 341(2), 69-78. https://doi.org/10.1111/1574-6968.12087

Marques, S. G., Conceição, D. M. P. S., Saldanha, P. C., Rezende, M. A., Vicente, V. A., Queiroz-Telles, F., \& Costa, J. M. L. (2006). Isolation of Fonsecaea pedrosoi from the Shell of the Babassu Coconut (Orbignya phalerata Martius) in the Amazon Region of Maranhão Brazil. Nihon Ishinkin Gakkai zasshi = Japanese journal of medical mycology, 47(4), 305-311. https://doi.org/10.3314/jjmm.47.305

Mayer, K. J., Sauer, J. S., Dinasquet, J., \& Prather, K. A. (2020). CAICE Studies: Insights from a Decade of Ocean-Atmosphere Experiments in the Laboratory. Accounts of chemical research, 53(11), 2510-2520. https://doi.org/10.1021/acs.accounts.0c00504

Mello, B. (2018). Estimating TimeTrees with MEGA and the TimeTree Resource. Molecular biology and evolution, 35(9), 23342342. https://doi.org/10.1093/molbev/msy133

Mourad, A. I., \& Haber, R. M. (2020). Visual Dermatology: Extensive Chromoblastomycosis of the Leg Secondary to Fonsecaea pedrosoi. Journal of cutaneous medicine and surgery, 26(1), 101. https://doi.org/10.1177/1203475420960434

Mouton, M., Postma, F., Wilsenach, J., \& Botha, A. (2012). Diversity and characterization of culturable fungi from marine sediment collected from St. Helena Bay, South Africa. Microbial ecology, 64(2), 311-319. https://doi.org/10.1007/s00248-012-0035-9

Najafzadeh, M. J., Gueidan, C., Badali, H., Van Den Ende, A. H. G. G., Xi, L., \& De Hoog, G. S. (2009). Genetic diversity and species delimitation in the opportunistic genus Fonsecaea. Medical mycology, 47(1), 17-25. https://doi.org/10.1080/13693780802527178

Najafzadeh, M. J., Vicente, V. A., Sun, J., Meis, J. F., \& de Hoog, G. S. (2011). Fonsecaea multimorphosa sp. nov, a new species of Chaetothyriales isolated from a feline cerebral abscess. Fungal Biology, 115(10), 1066-1076. https://doi.org/10.1016/j.funbio.2011.06.007

Narayanasamy, S., Dat, V. Q., Thanh, N. T., Ly, V. T., Chan, J. F., Yuen, K., Ning, C., Liang, H., Li, L., Chowdhary, A., Youngchim, S., Supparatpinyo, K., Aung, N. M., Hanson, J., Andrianopoulos, A., Dougherty, J., Govender, N. P., Denning, D. W., Chiller, T., Thwaites, G., van Doorn, H. R., Perfect, J., \& Le, T. (2021). A global call for talaromycosis to be recognised as a neglected tropical disease. The Lancet. Global health, 9(11), e1618-e1622. https://doi.org/10.1016/S2214$109 \times(21) 00350-8$

National Hurricane Center and Central Pacific Hurricane Center National Oceanic and Atmospheric Administration. (2022). Tropical Cyclone Climatology Retreved 2022-1-5 from httpss://www.nhc.noaa.gov/climo/

Paniz-mondolfi, A., Colella, M., Negrín, D., Aranzazu, N., Oliver, M., Reyes-jaimes, O., \& Pérez-alvarez, A. (2008). Extensive chromoblastomycosis caused by Fonsecaea pedrosoi successfully treated with a combination of amphotericin B and itraconazole. Medical mycology (0xford), 46(2), 179-

184. https://doi.org/10.1080/13693780701721856

Qin, X., Yang, K., Li, J., Wang, C., \& Shao, C. (2015). Phylogenetic diversity and antibacterial activity of culturable fungi derived from the zoanthid Palythoa haddoni in the South China Sea. Marine biotechnology (New York, N.Y.), 17(1), 99-109. https://doi.org/10.1007/s10126-014-9598-4

Queiroz-Telles, F., de Hoog, S., Santos, D. W., Salgado, C. G., Vicente, V. A., Bonifaz, A., Roilides, E., Xi, L., Azevedo, C. M., Da, S. M., Pana, Z. D., Colombo, A. L., \& Walsh, T. J. (2017). Chromoblastomycosis. Clinical microbiology reviews, 30(1), 233-276. https://doi.org/10.1128/CMR.00032-16

Rahaman, M. S., Siraj, M. A., Sultana, S., Seidel, V., \& Islam, M. A. (2020). Molecular Phylogenetics and Biological Potential of Fungal Endophytes from Plants of the Sundarbans Mangrove. Frontiers in Microbiology, 11, 570855. https://doi.org/10.3389/fmicb.2020.570855

Rämä, T., Davey, M. L., Nordén, J., Halvorsen, R., Blaalid, R., Mathiassen, G. H., Alsos, I. G., \& Kauserud, H. (2016). Fungi Sailing the Arctic Ocean: Speciose Communities in North Atlantic Driftwood as Revealed by High-Throughput Amplicon Sequencing. Microbial ecology, 72(2), 295-

304. https://doi.org/10.1007/s00248-016-0778-9

Rédou, V., Ciobanu, M. C., Pachiadaki, M. G., Edgcomb, V., Alain, K., Barbier, G., \& Burgaud, G. (2014). In-depth analyses of deep subsurface sediments using 454-pyrosequencing reveals a reservoir of buried fungal communities at record-breaking depths. FEMS microbiology ecology, 90(3), 908- 
921. https://doi.org/10.1111/1574-6941.12447

Rédou, V., Navarri, M., Meslet-Cladière, L., Barbier, G., \& Burgaud, G. (2015). Species richness and adaptation of marine fungi from deep-subseafloor sediments. Applied and environmental microbiology, 81(10), 3571-3583. https://doi.org/10.1128/AEM.04064-14

Riess, K., Schön, M. E., Lutz, M., Butin, H., Oberwinkler, F., \& Garnica, S. (2016). Correction: On the Evolutionary History of Uleiella chilensis, a Smut Fungus Parasite of Araucaria araucana in South America: Uleiellales ord. nov. in Ustilaginomycetes. PloS one, 11(3),

e0152646. https://doi.org/10.1371/journal.pone.0152646

Rojas-Jimenez, K., Grossart, H., Cordes, E., \& Cortés, J. (2020). Fungal Communities in Sediments Along a Depth Gradient in the Eastern Tropical Pacific. Frontiers in Microbiology, 11, 575207. https://doi.org/10.3389/fmicb.2020.575207

Santos, A. L. S., Palmeira, V. F., Rozental, S., Kneipp, L. F., Nimrichter, L., Alviano, D. S., Rodrigues, M. L., \& Alviano, C. S. (2007). Biology and pathogenesis of Fonsecaea pedrosoi, the major etiologic agent of chromoblastomycosis. FEMS microbiology reviews, 31(5), 570-591. https://doi.org/10.1111/j.15746976.2007.00077.x

Santos, D. W. C. L., de Azevedo, C. D. M. P., Vicente, V. A., Queiroz-Telles, F., Rodrigues, A. M., de Hoog, G. S., Denning, D. W., \& Colombo, A. L. (2021). The global burden of chromoblastomycosis. PLoS Neglected Tropical Diseases, 15(8), e9611. https://doi.org/10.1371/journal.pntd.0009611

Schwalb, A., \& Seas, C. (2020). Chromoblastomycosis. The New England journal of medicine, 383(2), e7. https://doi.org/10.1056/NEJMicm1913199

Shen, X., Dai, X., Xie, Z., Li, P., Lu, S., Li, J., Zhang, Y., \& Ye, X. (2020). A Case of Chromoblastomycosis Caused by Fonsecaea pedrosoi Successfully Treated by Oral Itraconazole Together with Terbinafine. Dermatology and therapy, 10(2), 321-327. https://doi.org/10.1007/s13555-020-00358-y

Singh, N., Agarwal, R., Gupta, D., Shivaprakash, M. R., \& Chakrabarti, A. (2006). An unusual case of mediastinal mass due to Fonsecaea pedrosoi. The European respiratory journal, 28(3), 662-664. https://doi.org/10.1183/09031936.06.00144505

Steenwyk, J. L., Shen, X., Lind, A. L., Goldman, G. H., \& Rokas, A. (2019). A Robust Phylogenomic Time Tree for Biotechnologically and Medically Important Fungi in the Genera Aspergillus and Penicillium. mBio, 10(4) https://doi.org/10.1128/mBio.00925-19

Takei, H., Goodman, J. C., \& Powell, S. Z. (2007). Cerebral phaeohyphomycosis caused by ladophialophora bantiana and Fonsecaea monophora: report of three cases. Clinical neuropathology, 26(1), 21-27. https://doi.org/10.5414/npp26021

Taylor, J. D., \& Cunliffe, M. (2016). Multi-year assessment of coastal planktonic fungi reveals environmental drivers of diversity and abundance. The ISME journal, 10(9), 2118-2128. https://doi.org/10.1038/ismej.2016.24

Taylor, J. W., \& Berbee, M. L. (2006). Dating divergences in the Fungal Tree of Life: review and new analyses. Mycologia, 98(6), 838-849.

https://doi.org/10.3852/mycologia.98.6.838

Tedersoo, L., Mikryukov, V., Anslan, S., Bahram, M., Khalid, A. N., Corrales, A., Agan, A., Vasco Palacios, A. M., Saitta, A., Antonelli, A., Rinaldi, A. C., Verbeken, A., Sulistyo, B. P., Tamgnoue, B., Furneaux, B., Ritter, C. D., Nyamukondiwa, C., Sharp, C., Marín, C., Dai, D. Q., Gohar, D., Sharmah, D., Biersma, E. M., Cameron, E. K., De Crop, E., Otsing, E., Davydov, E. A., Albornoz, F. E., Brearley, F. Q., Buegger, F., Gates, G., Zahn, G., Bonito, G., Hiiesalu, I., Hiiesalu, I., Zettur, I., Barrio, I. C., Pärn, J., Heilmann Clausen, J., Ankuda, J., Kupagme, J. Y., Sarapuu, J., Maciá Vicente, J. G., Fovo, J. D., Geml, J., Alatalo, J. M., Alvarez Manjarrez, J., Monkai, J., Põldmaa, K., Runnel, K., Adamson, K., Bråthen, K. A., Pritsch, K., Tchan, K. I., Armolaitis, K., Hyde, K. D., Newsham, K. K., Panksep, K., Adebola, L. A., Lamit, L. J., Saba, M., Da Silva Cáceres, M. E., Tuomi, M., Gryzenhout, M., Bauters, M., Bálint, M., Wijayawardene, N., Hagh Doust, N., Yorou, N. S., Kurina, O., Mortimer, P. E., Meidl, P., Nilsson, R. H., Puusepp, R., Casique Valdés, R., Drenkhan, R., Garibay Orijel, R., Godoy, R., Alfarraj, S., Rahimlou, S., Põlme, S., Dudov, S. V., Mundra, S., Ahmed, T., Netherway, T., Henkel, T. W., Roslin, T., Fedosov, V. E., Onipchenko, V. G., Yasanthika, W. A. E., Lim, Y. W., Piepenbring, M., Klavina, D., Kõljalg, U., \& Abarenkov, K. (2021). The Global Soil Mycobiome consortium dataset for boosting fungal diversity research. Fungal Diversity, 111, 573588. https://doi.org/10.1007/s13225-021-00493-7

Vargas-Gastélum, L., \& Riquelme, M. (2020). The Mycobiota of the Deep Sea: What Omics Can Offer. Life (Basel, Switzerland), 10(11),292. https://doi.org/10.3390/life10110292

Varghese, P., Jalal, M., Ahmad, S., Khan, Z., Johny, M., Mahadevan, P., Joseph, L., Chandy, R., \& Paul, S. (2016). CEREBRAL PHAEOHYPHOMYCOSIS CAUSED BY FONSECAEA MONOPHORA: FIRST REPORT FROM INDIA. International Journal of Surgery and Medicine, 2(1), 44. https://doi.org/10.5455/ijsm.neurosurgery01

Vicente, V. A., Attili-Angelis, D., Pie, M. R., Queiroz-Telles, F., Cruz, L. M., Najafzadeh, M. J., de Hoog, G. S., Zhao, J., \& Pizzirani-Kleiner, A. (2008). Environmental isolation of black yeast-like fungi involved in human infection. Studiess in Mycology, 61, 137-144. https://doi.org/10.3114/sim.2008.61.14

Vicente, V. A., Najafzadeh, M. J., Sun, J., Gomes, R. R., Robl, D., Marques, S. G., Azevedo, C. M. P. S., \& de Hoog, G. S. (2014). Environmental siblings of black agents of human chromoblastomycosis. Fungal Diversity, 65, 47-63. https://doi.org/10.1007/s13225-013-0246-5

Vicente, V. A., Orelis-Ribeiro, R., Najafzadeh, M. J., Sun, J., Guerra, R. S., Miesch, S., Ostrensky, A., Meis, J. F., Klaassen, C. H., de Hoog, G. S., \& Boeger, W. A. (2012). Black yeast-like fungi associated with Lethargic Crab Disease (LCD) in the mangrove-land crab, Ucides cordatus (Ocypodidae). Veterinary microbiology, 158(1-2), 109-122. https://doi.org/10.1016/j.vetmic.2012.01.031

Page $11 / 17$ 
Vicente, V. A., Weiss, V. A., Bombassaro, A., Moreno, L. F., Costa, F. F., Raittz, R. T., Leão, A. C., Gomes, R. R., Bocca, A. L., Fornari, G., de Castro, R. J. A., Sun, J., Faoro, H., Tadra-Sfeir, M. Z., Baura, V., Balsanelli, E., Almeida, S. R., Dos Santos, S. S., Teixeira, M. D. M., Soares Felipe, M. S., do Nascimento, M. M. F., Pedrosa, F. O., Steffens, M. B., Attili-Angelis, D., Najafzadeh, M. J., Queiroz-Telles, F., Souza, E. M., \& De Hoog, S. (2017). Comparative Genomics of Sibling Species of Fonsecaea Associated with Human Chromoblastomycosis. Frontiers in Microbiology, 8, 1924. https://doi.org/10.3389/fmicb.2017.01924

Wainwright, B. J., Zahn, G. L., Spalding, H. L., Sherwood, A. R., Smith, C. M., \& Amend, A. S. (2017). Fungi associated with mesophotic macroalgae from the 'Au'au Channel, west Maui are differentiated by host and overlap terrestrial communities. PeerJ, 5, e3532. https://doi.org/10.7717/peerj.3532

Wallis, M. C., Waters, P. D., \& Graves, J. A. M. (2008). Sex determination in mammals-before and after the evolution of SRY. Cellular and molecular life sciences: CMLS, 65(20), 3182-3195. https://doi.org/10.1007/s00018-008-8109-z

Wijesekera, K., Mahidol, C., Ruchirawat, S., \& Kittakoop, P. (2017). Metabolite diversification by cultivation of the endophytic fungus Dothideomycete sp. in halogen containing media: Cultivation of terrestrial fungus in seawater. Bioorganic \& medicinal chemistry, 25(11), 2868-

2877. https://doi.org/10.1016/j.bmc.2017.03.040

You, Z., Yang, X., Yu, J., Zhang, J., \& Ran, Y. (2019). Chromoblastomycosis Caused by Fonsecaea nubica: First Report in Northern China and Literature Review. Mycopathologia, 184(1), 97-105. https://doi.org/10.1007/s11046-018-0307-0

Zhang, R., Ran, Y., Zhang, H., Dai, Y., Ran, X., Zhang, C., Qin, W., \& Xi, L. (2019). A Case of Chromoblastomycosis Caused by Fonsecaea Pedrosoi and Investigation of the Pathogenic Fungi. Mycopathologia, 184(2), 349-352. https://doi.org/10.1007/s11046-019-0319-4

\section{Supplementary Tables}

Supplementary Tables 1 and 2 are not available with this version.

\section{Figures}
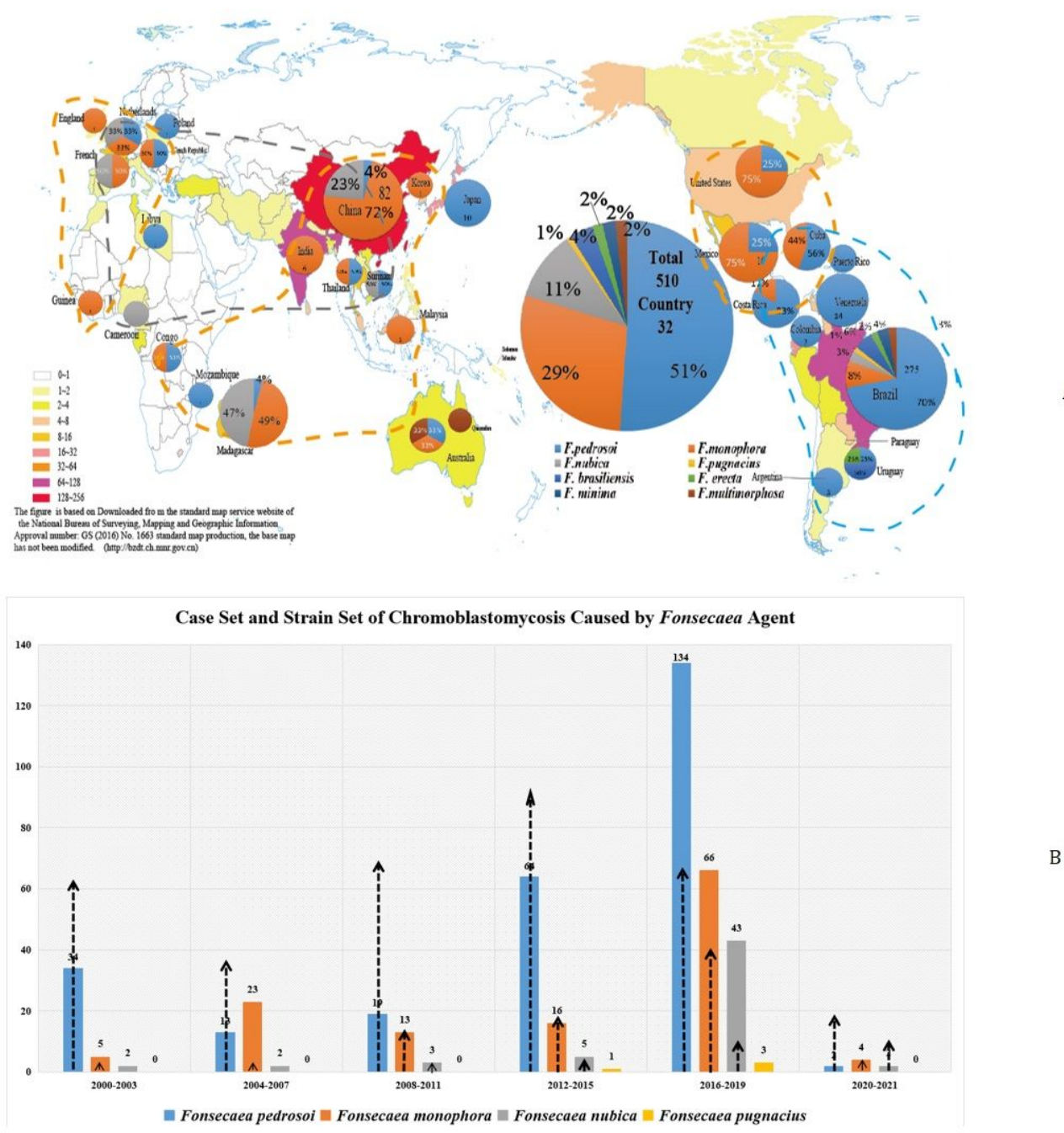

Figure 1 
Fig. $1 \mathrm{~b}$ the plot is divided into groups at 4-year intervals, with the interval 20000-2021; the vertical coordinates are the count values (0-140), and the 4 colors represent the 4 species of Fonsecaea spp. The height of the bar graph represents the number of corresponding fungal species collected at 4-year intervals; the arrows indicate: the number of reported cases of the corresponding fungal species at 4-year intervals.

Fig. $1 \mathrm{~b}$ the plot is divided into groups at 4-year intervals, with the interval 20000-2021; the vertical coordinates are the count values (0-140), and the 4 colors represent the 4 species of Fonsecaea spp. The height of the bar graph represents the number of corresponding fungal species collected at 4-year intervals; the arrows indicate: the number of reported cases of the corresponding fungal species at 4-year intervals

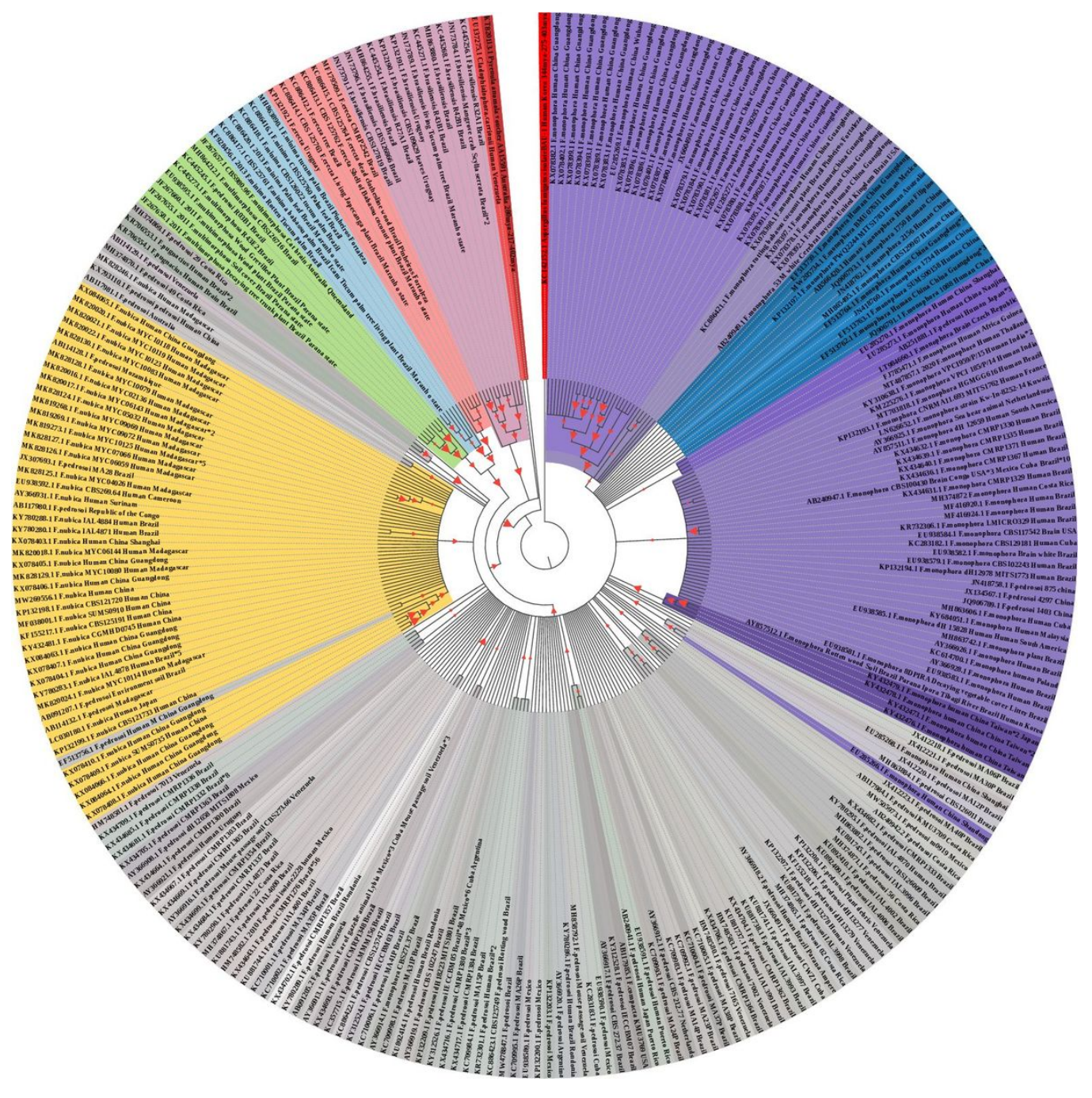

Figure 2

Global sequence phylogenetic tree. Each color category represents a strain of Fonsecaea spp. The subtle shades in each color category represent each collected strain of Fonsecaea spp. The red color represents a consistent reference fungus, The phylogenetic tree source is available at: https://itol.embl.de/tree/1152322311164021641970447 


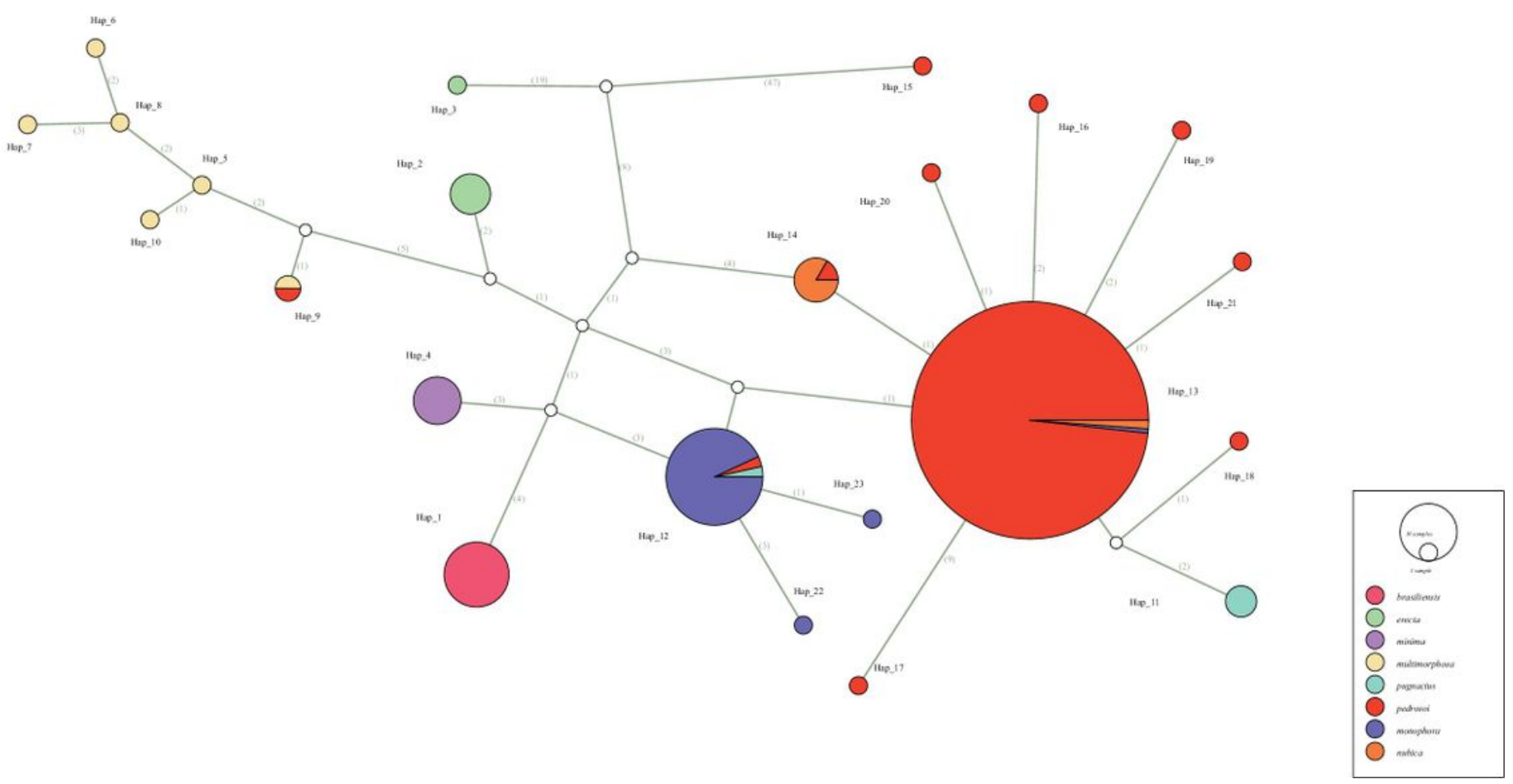

\section{Figure 3}

Haplotype network using combined Ribosomal internal Transcribed Spacer (ITS) of Fonsecaea spp . sequence data from Brazil, with geographical distribution, gaps and missing data excluded. In combined ITS sequence data of Fonsecaea spp. Each color corresponds to a strain of fungal species. The size of the circle represents the number of matched samples

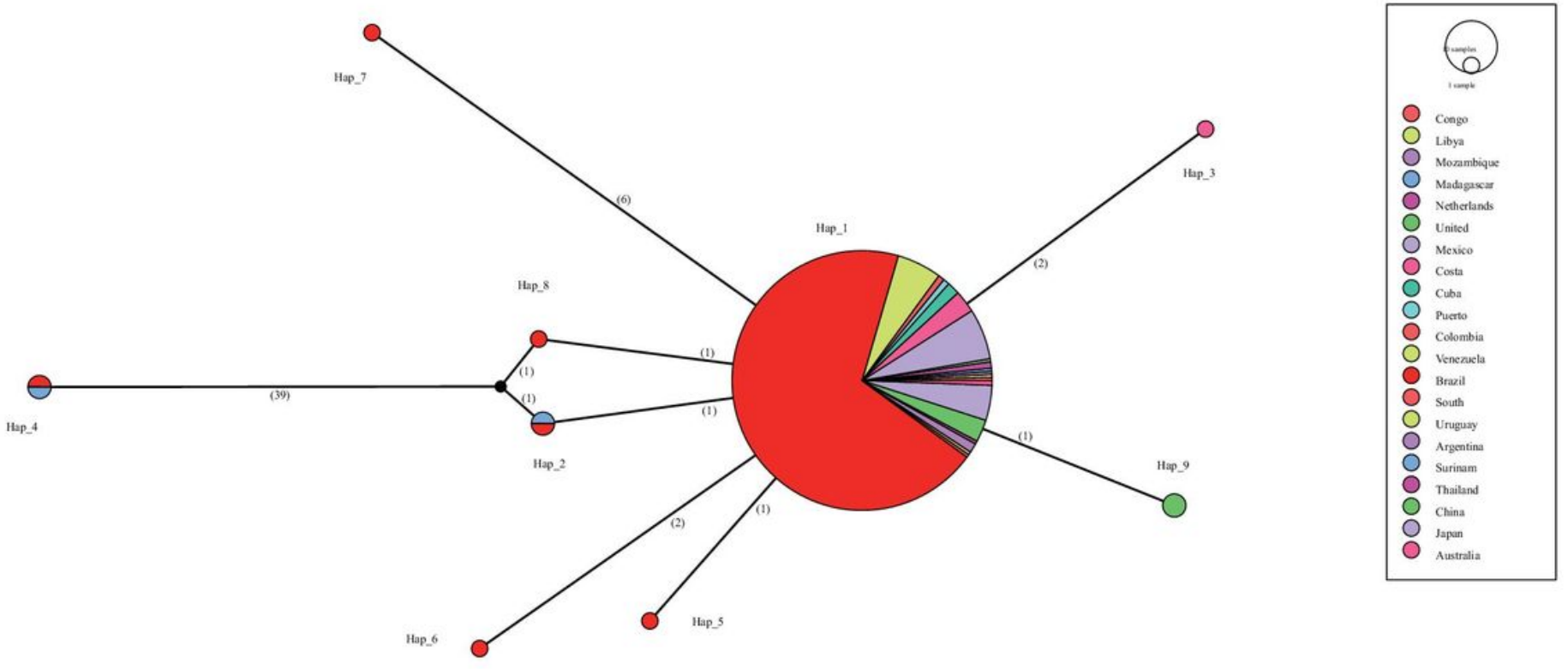


Figure 4

Global distribution pattern of the haploid network of Fonsecaea pedrosoi. Each color represents a country. The size of the circle represents the number of samples

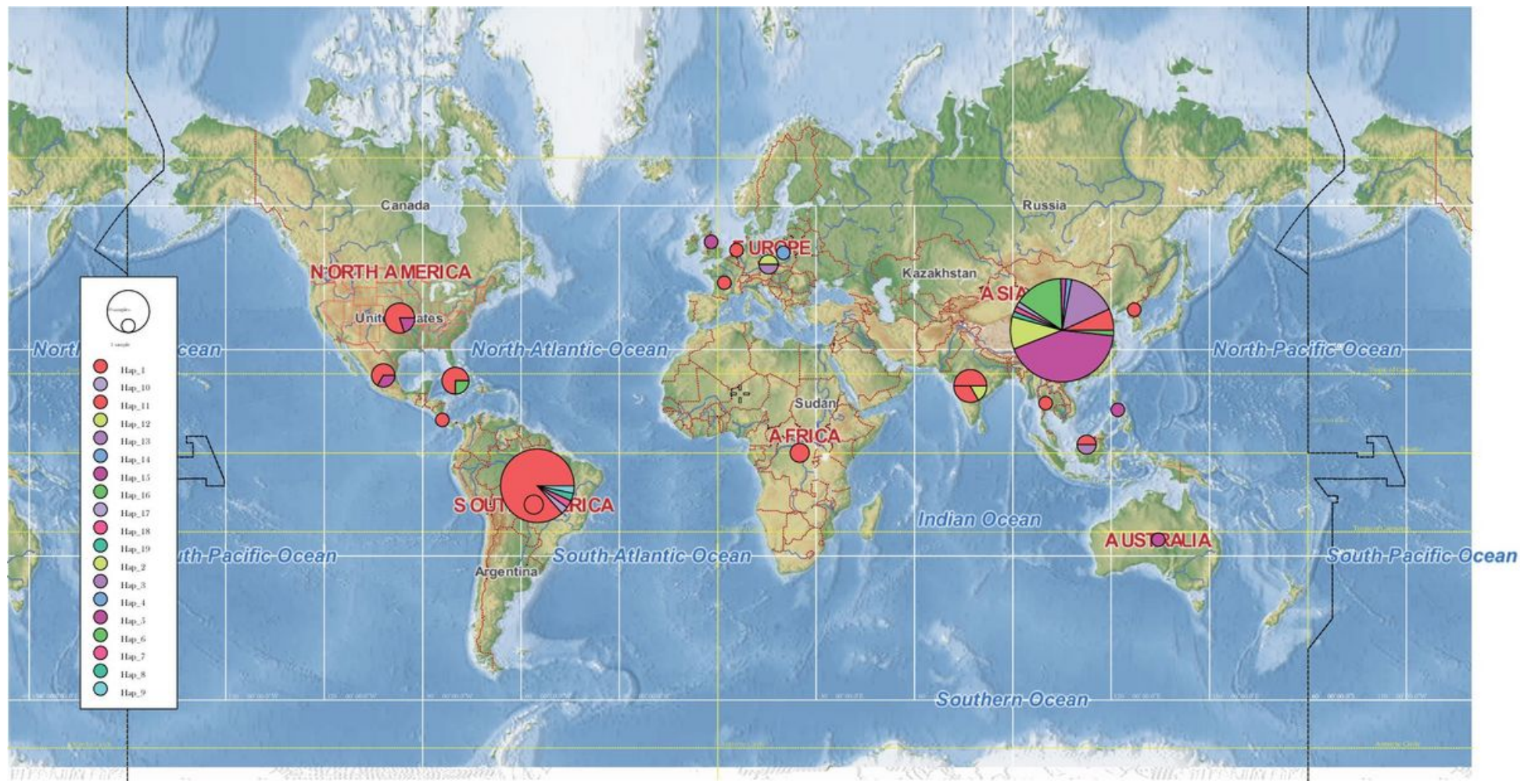

\section{Figure 5}

Global distribution pattern of the haplotype network of Fonsecaea nubica. Each color represents a haploid genetic subtype. The size of the circle represents the number of samples

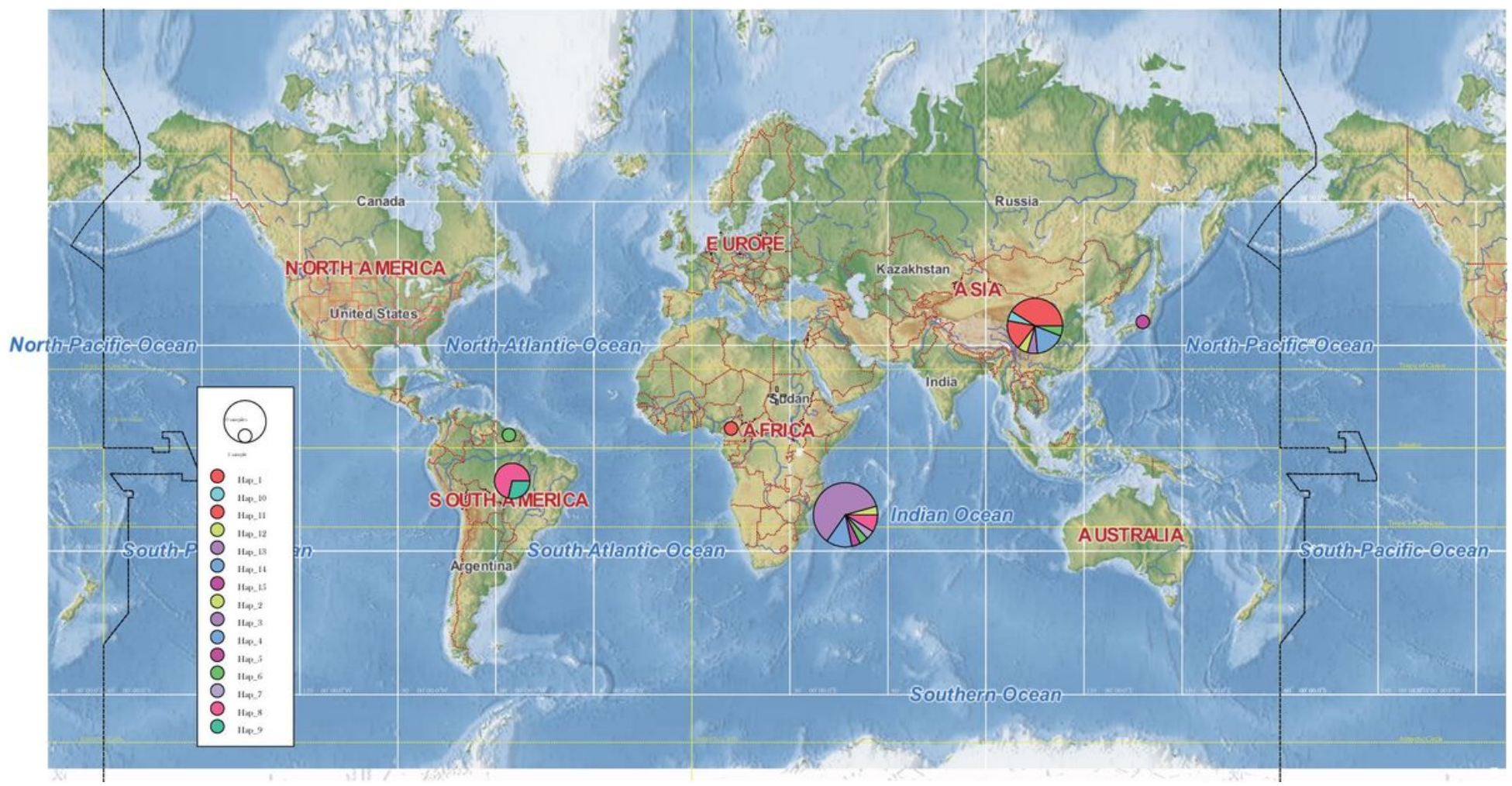




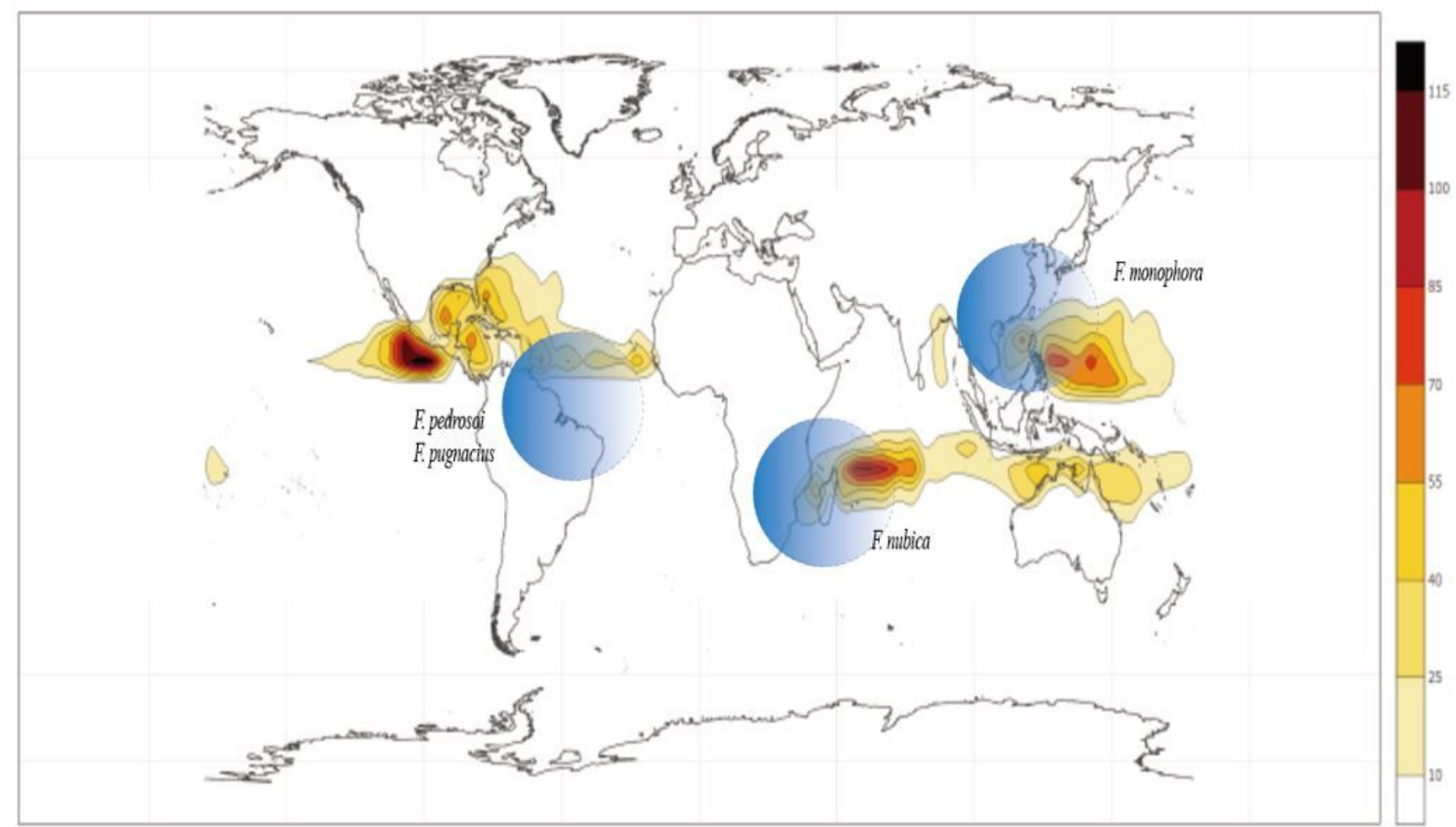

Blue gradient circles: schematic diagram of the possible range of origin of pathogenic species Map of the origin of tropical cyclones: https://chart-studio.plotly.com/ ToniBois/3306.embed

Figure 7

Hypothesis on the origin and global dispersal of strains of Fonsecaea spp. The blue gradient circles indicate the range of transmission origins of different strains of Fonsecaea spp. The colored contours indicate locations of the origins of tropical cyclones; darker red means more frequent origins of tropical cyclones 


\section{Hypothesis on the Relationship Between Fungal Transmission and Dispersal of Genus Fonsecae and Tropical Cyclones}

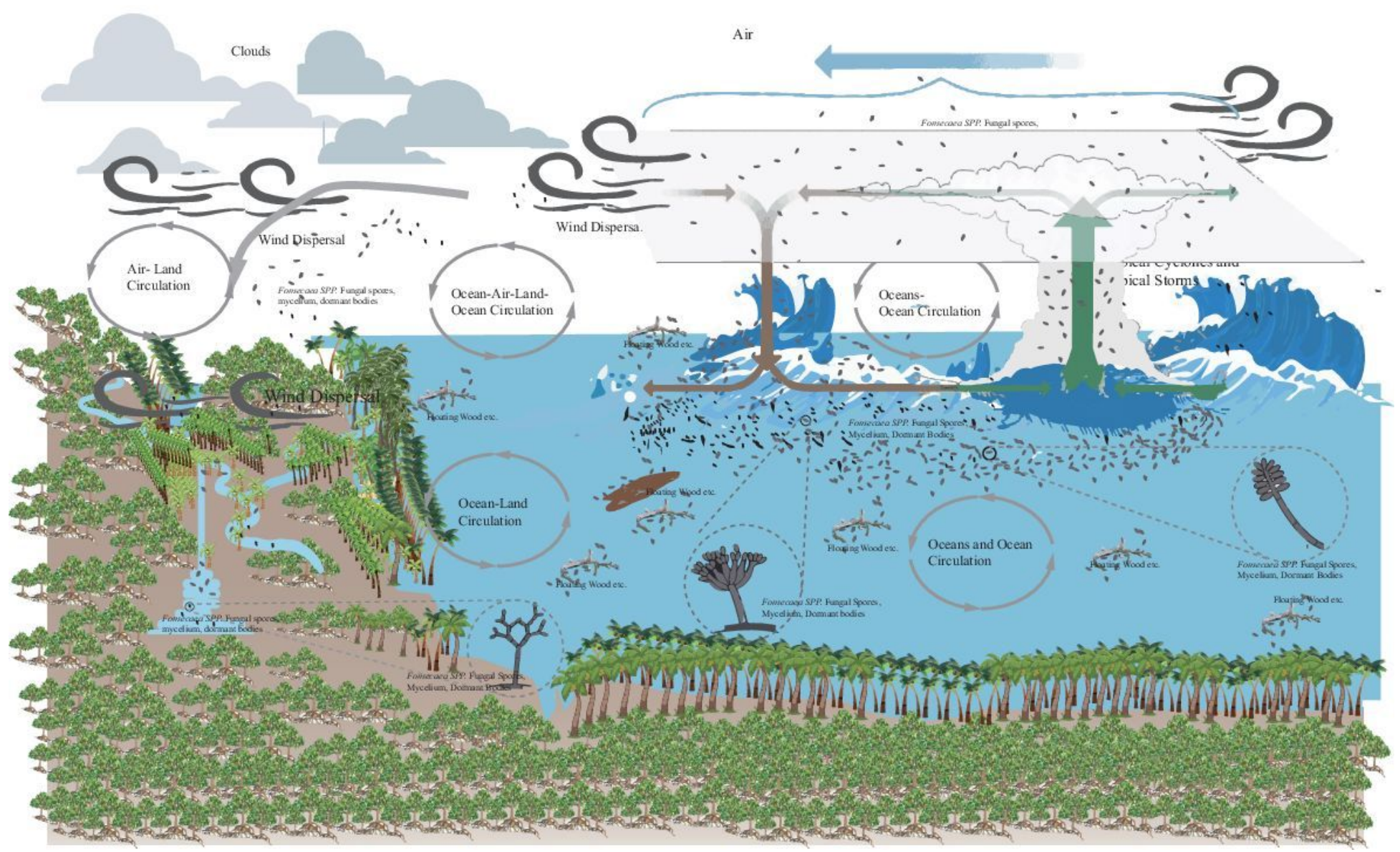

Figure 8

Graphical representation of our hypothesis for the global mode of dispersal of Fonsecaea spp.

\section{Supplementary Files}

This is a list of supplementary files associated with this preprint. Click to download.

- fonsecaeaquc194.pdf 